\title{
On Truthful Narrative-Identity and a Development Model for Nigeria
}

\author{
Anthony C. Ajah \\ Department of Philosophy, University of Nigeria, Nsukka, Nigeria \\ Email: anthony.ajah@unn.edu.ng
}

Received 3 September 2014; revised 25 September 2014; accepted 18 October 2014

Copyright (C) 2014 by author and Scientific Research Publishing Inc.

This work is licensed under the Creative Commons Attribution International License (CC BY). http://creativecommons.org/licenses/by/4.0/

(c) (i) Open Access

\section{Abstract}

There have been several development models. Each of these models attempts to identify the causal and explanatory factors that can explain why some societies are developed or underdeveloped, or how those that are underdeveloped can (if they can) improve on their wellbeing. Some of these models are: modernization model, economic development model, dependency model, human development model, and so on. I intend to argue in this paper that most of these development models, especially the dependency model, are faulty because they sustain irresponsibility, and are therefore dehumanizing. In their place, I argue in this paper for the culture-agency model of development which is based on the logic that development is the result of human actions. Human actions are results of human choices. Human choices are results of human valuation systems. Valuation systems are aspects of a people's culture. Thus, the best development model is one that puts the members of every society at the centre of their development process and developmental activities. Based on my analyses of the Igbo expression that "eziokwu bu ndu" (truth is life) and Paul Ricoeur's idea of narrative-identity, I establish in this paper, a close connection between truth (which results from the narrative-identity of/by a people about themselves) and social development. I did this with some particular reference to Nigeria.

\section{Keywords}

Development, Culture-Agency, Eziokwu, Igbo, Choice, Narrative-Identity, Ricoeur

\section{Introduction}

There has been an interesting debate about development, and development in Africa. Some of the attempts to contribute to this debate were made by: Rodney (1972), Harrison (1985), Nussbaum and Sen (1993), Diamond (1997), Agbakoba (1998), Landes (1999), Harrison and Huntington (2000), Sen (2000), Oguejiofor (2001), 
Nussbaum (2001), Mkandawire (2001), Agbakoba (2003), Njoku (2004), Sachs (2005), Diamond (2005), Willis (2005), Meredith (2006), Meyns and Musamba (2010), Drèze and Sen (2013), and so on. These and so many others have paid attention to issues about what development means, why some societies are more developed than others, whether less-developed states can catch-up with more developed states; if such catch-up is possible, what development model or strategy should be employed both to understand the differences in the developmental state of countries and to enable less-developed countries do better.

In the course of this debate, there have also been several changes in the conceptions of what development is, and what parameters are more suitable for the assessment of the developmental level of countries. There was the 1950s general conception of development as modernization. There was also the 1960s and 1970s conception of development as economic progress. In the 1980s and 1990s, there emerged the concept of not just development, but human development. The reason for this addition of a qualifier was that some authors, following the United Nations, argued that the major factor in the measurement of development index (namely, GNP per capita) leaves so many other important factors and development indicators unaccounted for. The Central European University (2012) explained more about the conception of development as human development. It recalled that two decades ago (that is, in 1990), the first Global Human Development Report gave birth to a new concept of development, namely, the human development concept. This concept of development aimed on people, and this is how it differed from earlier conceptions of development. To provide yet further clarifications on this concept, Andrey Ivanov (n.d) noted that the message of this conception of development is clear: people are the objective, not the means of development; money is a means, and not an end in itself; meeting basic needs for goods and services is important, but only in the context of other broader issues, namely, freedom, democracy, gender, environment, community, culture. In addition, freedom of choice and the expansion of people's choices, no matter their contexts, are the priorities in a human development context. Meanwhile, the observable differences in the attainment of wellbeing in each context, constitute the basis for the comparison among countries: between those who truly desire and work to achieve the development of their societies (and the resultant improvement in their well-being), and those who do not seem to truly desire and therefore do not work truly hard to improve the wellbeing of the members of their societies-against whatever may be the odds. The last group of countries (most of which are African countries) are those whose developmental state is worrisome.

\section{Developmental State of Africa}

The concept "developmental state" is relatively new in development discourses. It stems from the conviction, in so many quarters, that African societies cannot catch-up with the West in the development ladder, or simply, that African countries cannot overcome their experiences of development crisis. This is sampled by one of Jeffrey Sachs (2002: p. 310) sarcastic sub-heading on the presupposition that "Aid Programs Would Fail in Africa". Arguments in discourses on Africa's developmental state have always focused on whether African countries do at all desire development, and whether they have the structures and facilities that make development to happen. First of all, I consider Thandika Mkandawire's definition of developmental state. According to him, there are two predominant and defining components of the various definitions of the term "developmental state": one is an ideological component, the other structural. The ideological component conceives economic development as the mission of the state. The structural component on the other hand looks at the state as having the responsibility to develop the (technical, administrative and political) capacities as the conditions that make effective implementation of development-enhancing policies possible (Mkandawire, 2001).

Mkandawire, however, had some reservations for this ideology-structure nexus in the definition of what developmental state means - or should mean. According to him, one remarkable feature of the discourse on Africa's developmental state is the disjuncture between an analytical tradition and a prescriptive one. While the authors in the first tradition engage themselves in a diagnosis to determine which countries are at what stage in their development process (or have the capacity to pursue any national project), the authors in the second tradition "exhort" poor countries, on the basis of the result of the diagnosis, "to assume roles that are, ex definicione, beyond their capacity, character or political will... In other words, to do what they cannot do. What we then have is, to paraphrase Gramsci, the pessimism of the diagnosis and optimism of the prescription” (Mkandawire, p. 289). Mkandawire's worry is that there is a widespread pessimism-by Africans and non-Africans alike-about Africa's ability to be a developmental state; in fact, to develop. Contrary to this, he argued that neither Africa's post-colonial history nor the actual practice engaged in by successful "developmental states" rule out the possi- 
bility of African developmental states capable of playing a more dynamic role than hitherto. In fact, in Mkandawire's view, this pessimism is a result of "misreading of experiences in Africa", and a consequent conviction that there are no developmental states in Africa as sampled in statements like "the way Africa works" (pp. 290-293).

On her part, Charity Musamba (2010: p. 13) defines a “'developmental' or 'plan-rational state”” as "one that is determined to influence the direction and pace of economic development by directly intervening in the developmental process, rather than relying on the uncoordinated influence of market forces to allocate economic resources". She listed the features of a developmental state to include: 1 ) development-oriented political leadership; 2) autonomous and effective bureaucracy; and 3) production-oriented private sector. According to Musamba and Meyns (2010), other features of a developmental state are: a) adequate state capacity; b) comprehensive development strategy; and c) determined focus on development (2010: pp. 21-26). However, Musamba (2010) noted that the pessimist positions mentioned by Mkandawire (2001) usually lead to the impossibility theorem prevalent in development discourses on Africa. Musamba and Meyns (2010) agree with Mkandawire (2001) that the "impossibility theorem" is faulty. The views of the proponents of that theorem are typically represented in Jeffrey Sachs' idea that no matter the effort, development attempts will always fail in Africa. It seems to me Sachs took such a position because there has remained very little or no consistent effort to really look at the African as a reliable agent of social development. This is why I consider it necessary to reflect on the culture-agency development model.

\section{Arguments for the Culture-Agency Model of Development}

A development model (or theory) is an articulation of the principles and mechanisms that can best explain why societies have developed more than others, why less developed ones are the way they are, how less developed ones can (if they can) develop, and why less developed societies cannot catch-up (if they cannot catch-up). According to Agbakoba (2003), theories of development are meant to tell us what the future states of a society may look like. They help achieve the goals they set out by the self-validating fact of people believing in the theory and acting upon such a belief and the predictions it warrants. It is in this claim to the ability to predict, that some theories vary from each other on the same issues. In Agbakoba's views, some theories emphasize determinism, while others emphasize the freewill of the social agents seeking to develop themselves. In the provision of the explanations for what have happened and why societies are as they are, some theories are classed as teleological, while others prefer the causal explanation of the situations under discussion.

Willis (2005) made some distinctions among "Classical and Neo-Liberal development theories", and "Structuralist, Neo-Marxist, and Socialist development theories". In the case of the first set of theories, she sampled Adam Smith's theory on free market economy, John Keynes' theory of economic development, modernization development theories, development as a result of aids, and neo-liberalism. The second set of theories include: Marxist theories of development, dependency theory as a structuralist development theory, socialism and its soviet model, Maoism and its influence in China's development, and African socialism and Afro-Marxism. Besides these, there have also been other attempts to explain why some countries are less developed than others; why some of the countries are less developed even though they have all the human and natural resources necessary to place them on a high level on the development ladder; what less developed countries "need" (or in some cases, some authors prefer to write "ought") to do to be able to improve their situation. Some of the post-independence development theories involved here engage in explanations of underdevelopment on the basis of such factors as: geography (climate and environment), historical experiences (slavery, colonialism, neo-colonialism), the structure of contemporary international trade (structures that create and sustain dependency, globalization, the effect of the arrangement of international trade on the underdevelopment of weak countries), and culture. As is evident, many of these factors are closely related to those listed above in Willis' classification, and are explainable within Agbakoba's framework on the focus or emphases of development theories.

Jared Diamond (1997) argued to support the view that geographical location of countries and continents determined their development pace. In line with the views of Diamond (1997), Sachs (2000) expressed a conviction that geography is a determining factor in the understanding and explanation of the development pace of countries and regions. As a response to those who point at the quality of governance in African societies as the fact responsible for Africa's underdevelopment crisis, Sachs argued that "There is distinctly slower growth in Africa even after controlling for the quality of governance. Something else is afoot; as I have argued at length, 
the slower growth is best explained by geographical and ecological factors” (p. 312). To emphasize the point elsewhere, and on the basis of the results of a research he conducted, Sachs noted that the purpose of the research was to check whether African countries can progress once the quality of governance and initial income had been considered. According to him, the results show that on the average, African countries grew around 3 percent points less rapidly than other developing countries at the same levels of governance and income. This slower growth is caused, "in my opinion, mainly by Africa's adverse geography and deficient infrastructure” (p. 312).

Rodney (1972) and Oguejiofor (2001) focused on the destructive impacts of slavery, colonialism, and neocolonialism on development in Africa. According to Rodney, these historical events were the foundations for Africa's fall from her self-attained level of development, and are still the explanations for the present dependency syndrome bedevilling the economies of African countries. On the basis of this argument, aids from more developed countries should be suspected, trade with them should be considered deceptive as much as it is dangerous, and globalization-the evident bonding of countries—needs to be seen as a monster! Writing on culture as the explanatory factor for development of societies, Weber (1930) had argued for the influence of the protestant ethic (a type of culture) on the development of the capitalist economy in Western Europe. His arguments have received supports from Harrison (1985), Harrison and Huntington (2000), Stark (2005), and so many others. Harrison (1985) had argued that the society that is most successful in helping all its people realize their creative potential is the society that will progress the fastest.

The idea of a society helping all of its people realize their creative potentials implies that while some societies may consciously desire and actually choose (with commitment) to help their members realize their potentials, some others may completely desire and choose otherwise. This brings with it a question of choice. Yet, since only rational agents can reflect-even if only in retrospect-about their choices, one identifies a commonplace (though very crucial) link among culture, agency and human development. This is because cultures belong to human agents. They are adjustable and or sustainable only by the choice of human agents. With culture being the way of life of a people, and social development the result of the actions that make-up and define every way of life of a people, what we call culture and development are no natural or special gifts meant for particular people from particular regions of the world. Instead, they are results of consciously calculated human actions. This is the reason for the idea of the culture-agency model of development.

The culture-agency model of development is the idea of development that explains the "why" and "how" about the development of societies from point of view of the fact that the human beings in every society are the ones who - by their interests, preferences, choices, actions, and inactions-determine the course, spread, and speed of the improvement of the wellbeing of the members of their societies. Human existence can only be truly defined, made meaningful, and understood from point of view of these words. They paint us as the agents who act and can adjust our actions. They demand that we see ourselves as responsible social agents. They are the words that define the whole idea of the culture-agency model of development which is intended as an improvement on the culture model of development.

But, are all the models of development so sketchily presented above equally valid and capable of providing productive and action-inspiring explanations for the development or and underdevelopment of societies? It is this question that is of great concern to me. This is because there is always the need to counter the genuine threat of relativity and subjectivity by being able to say objectively that one theory is better than another, and therefore has better recommendations for the developmental states of societies. To assist in providing a paradigm that can enable a fruitful comparison among the development models presented, Agbakoba (2003: p. 34) noted, in a realist tone, that "theories are not entirely a creation of the mind; they correspond to some objective reality". The interest on the comparison among conceptions of development is based on the assumption that there is both the need and possibility to identify some criteria (or at least a criterion) for determining the better theory. Agbakoba noted that a reliable criterion for distinguishing among theories consists in one theory observationally nesting another. This amounts to the rate at which the prediction of one theory is corroborated when observed and measured. This is described as the observational success of a theory. A theory's observational success indicates its approximation to the truth. Therefore, a theory is considered to observationally nest another, and is thus approximately true, when it not only preserves the observational success of the rival theory, but also improves on it. In addition to this single criterion, there are some other criteria for assessing which theory is better than other theories on the same subject: 1) a theory's fertility: that is, its ability to suggest possible developments and applications; 2) a theory's ability to explain the laws of other theories in the same field; 3) the smoothness of a 
theory: that is, the ease with which we can cover up or accommodate predictive failures by the use of auxiliary hypotheses (that is, secondary and still helpful hypotheses); and 4) a better theory should contain fewer inconsistencies, if any at all (Agbakoba, 2003: p. 34). These will be briefly explained by application in the next section on why I consider culture-agency theory to be a better development model.

\subsection{Culture-Agency Theory of Development as a Better Development Model}

\subsubsection{The Fertility of the Culture-Agency Theory of Development}

Development is a result of purpose-driven human actions; and all human actions are results of purposes and choices determined by predominant values and preferences. This is correct, even when these values and preferences are not clearly articulated and reflected upon. It is not in doubt that the predominance of particular social values in a particular context is an indication of a form of culture. Cultures are owned by rational social agents. These agents choose what values and purpose to drive their preferences and choices, and what culture to remain in. It is on the basis of this tightly knit relationship among purpose, choice, value, culture, and social development, that the culture-agency theory is regarded as a better theory of development than the several others presented above. It is here qualified as more "fertile" because it has the best capability to suggest improvements for social agents. This includes suggestions borrowable from other contexts. The dependency theory has no such fertility because it gives very little or no space for improvement. Arguments for geography lack such fertility also because they are too deterministic as Diamond (1997) suspected. The extreme forms of such arguments (still sampled in Diamond, 1997) foreclose almost completely opportunities for rational and choice-induced improvements by less developed countries.

\subsubsection{The Ability of the Culture-Agency Theory of Development to Explain the Laws of Other Development Models}

What is called dependency — as the core argument and law presented by the dependency theorists-is explainable by the culture-agency theory of development. This is the second reason the culture-agency theory of development is a better theory than dependency theory. Even the central concept in that theory ("dependency") presupposes a prior place of choice in the relationship between the dependent countries and those on whom they depend. By taking care of choice and more, the culture-agency theory proves its capacity to explain the laws of the dependency theory. On the other hand, bearing in mind that there are several choices a society can make to overcome some geography-imposed conditions, it becomes clear also how the culture-agency development theory explains the impacts of geography in social development. Because it is able to do this, the culture-agency theory is considered a better theory.

\subsubsection{On the Ease with Which the Predictive Failures of the Culture-Agency Theory of Development Can Be Accommodated}

Unlike the dependency theory and the explanation by geography, the culture-agency theory is not simplistic. It appreciates the complex nature of human existence, of human society, of the human person, and of his use of choice as an expression of his values and interests. Thus, the culture-agency theory has series of secondary hypotheses which can be handy and useful in explaining predictive failures, whereas the other two theories and explanation models are so simplistic that they lack the ease and smoothness to explain predictive failures.

\subsubsection{The Lack of Inconsistencies in the Culture-Agency Theory of Development}

There is no inconsistency in the logic of the culture-agency theory of development. This logic states that: 1) development is a result of conscious human actions; 2) human actions are given meaning, determined and guided by human choices; 3) what is called human choice flows from personal/social values and preferences; 4) social values are cultural elements that define the mode of comportment of every individual/group; 5) the values of the social agents in every society are the determining explanatory factors for the development state of such a society; and 6) therefore, if the values and preferences change, the choices will change, and the development trajectories will change too. This is the core argument of the culture-agency theory of development. This argument is consistent with human nature. The concept of human nature which defines it and gives it meaning is very consistent with the use of this concept of human nature by this theory in explaining how societies develop. This is another reason I consider the culture-agency model of development as the best theory of development. For these reasons, it is the most rational model for explaining and predicting human development in any human society. I will at- 
tempt to apply this model to explain the development crisis in Nigeria.

\subsection{Development Issues in Nigeria and the Application of the Culture-Agency Development Model}

In her awakening reflection on Nigeria and her development crisis, Obiageli Ezekwesili (2013) wrote about one of the obvious facts: Nigeria is a paradox of the kind of wealth that breeds penury. It is a nation blessed with abundance of ironies. These qualifications are right because the evident gap in the level of development between Nigeria and such countries as Singapore, South Korea, Chile, Malaysia, and Brazil was not initially there. Ezekwesili observed, very correctly, that in 1960, the GDP of all the countries so listed were not starkly different from that of Nigeria: two were below $\$ 200$, two were a little above $\$ 300$ and one was slightly above $\$ 500$ while that of Nigeria was just about $\$ 100$. After 51 years, that is, by 2011, the range for all five is between: Singapore at nearly $\$ 50,000$, South Korea at $\$ 220,000$, Malaysia at $\$ 10,000$, Brazil at $\$ 13,000$, and Chile at $\$ 14,000$. Unfortunately, in the case of Nigeria, her income per capita is $\$ 1500$. This helps drive home the point that the citizens have been left behind many times over by the citizens of every one of these other countries (Ezekwesili, 2013).

This is strange as it is mind-bugging. Ezekwesili was bugged and worried by the strange unpalatable fact. She wondered how these nations steer and stir their people to achieve such outstanding economic performance over the last five decades. She extended her reflection on the question of development and development models as these have to do with Nigeria. She wondered: "Again, how did this happen? What happened to Nigeria? Why did we get left behind? How did these nations become productively wealthy over the last fifty years while Nigeria stagnated?” (pp. 4-5). She accepted that there are usually as many different answers to these questions as there are respondents on the reasons Nigeria fell terribly behind her "peers". Some say it is the tropical geography within which Nigeria is located. But, Ezekwesili responded that economic research shows that geographical location has not prevented other countries with similar conditions from breaking through. Others who respond to the chain of questions say it is size. But, Ezekwesili retorted that China and India are bigger than Nigeria, yet, in the last thirty and twenty years, the two countries have grown double digit and continue to out-grow the rest of the world at this time of global economic crisis. Some others say it is Nigeria's culture that made her fall behind. But, Ezekwesili recalled that European countries with different sorts of cultures, Protestant and Catholic alike, have grown rich, and that even different countries within the same broad cultures have performed very differently in economic terms. The two Koreas in the post-war era are evident examples. To cap the position on culture, Ezekwesili argued that individual countries have changed their economic trajectories even though their cultures didn't miraculously change. Still, there are others who, in responding to the above questions about Nigeria's crisis, emphasize Nigeria's multiethnic nationalities as the constraint. In Ezekwesili's views, such authors fail to see that the Unites States of America happens to be one nation with even more disparate ethnic nationalities than Nigeria and yet it leads the global economy. For those who say it is the adverse effect of colonialism that made Nigeria and the entire African continent to be underdeveloped, Ezekwesili drew their attention to Singapore, Malaysia and even China, which are sample cases of countries which were similarly conquered and dominated by colonialists, but have continued to develop themselves.

One sees in the above submissions, attempts by Ezekwesili to rehearse the several arguments presented by the advocates of the several theories/models of development. She recalls these models as each of them has been applied to explain Nigeria's situation. Then, she took a stand-although not quite a clear stand. She argued that it was "resource wealth" that tragically reduced Nigeria to a mere parable of prodigality and self-inflicted failure. I refer to Ezekwesili's position as "not quite clear" because she blames both what is generally referred to as "resource wealth" and the idea of "self-inflicted failure". She explained that oil "unleashed" shocks and volatility of revenues on Nigeria's economy due to her exposure to global commodity market swing. Oil also "proliferated" weak, ineffectual, unstable and systematically corrupt institutions and bureaucracies that have helped misappropriate or plunder Nigeria's public resources. The common wonderment is exactly why more than half the population of a country that earned nearly one trillion dollars in oil revenue since the Oloibori discovery of crude oil would continue to wallow in poverty. According to her, economic evidence shows that the answer which we must all ponder deeply is that oil wealth entrenched corruption and mismanagement of resources in government and warped the incentive for value-added work, creativity and innovation in public, private sectors and wider society. The choice the oil revenue induced Nigeria's ruling elite into making, over the five decades of political 
independence, cursed several of Nigeria’s citizens to "intergenerational poverty" (p. 7). This was her position about development in Nigeria. I then indicate my reservations with some of her views.

Ezekwesili so personified the term "oil wealth" as though it were Nietzsche's superman. One observes that "oil wealth" is accorded such active verbs as "unleashed”, "proliferated”, "entrenched”, and "warped”. This is a form of unconscious argument for irresponsibility in which "oil wealth" is blamed while the human agents who manage the wealth are exonerated. It would be better to argue that since Nigeria discovered oil, due to Nigerians' preference for greed, their excessive self-interest, lack of management skills, poverty of transcendent values, and so on, majority of Nigeria's citizensand leaders have continued to prefer corruption, and display the poverty of management skills. Even this, is evident in the more correct aspect of Ezekwesili's argument, namely, her idea about choices induced by the oil wealth. Once this is understood as a more reasonable position than what is called "resource curse", or the view about poor (inanimate) oil "unleashing, proliferating, entrenching, and warping", then, Ezekwesili's reservations against the culture-agency theory would be weakened. This is because, the truth is this: we are the agents who chose and will continue to choose what happens in our societies and with our resources.

My use of the concept of truth in this reflection is truth in its correspondence understanding, that is, as the unity of what is expressed in propositional forms with what is intended or what exists concretely in reality (whether hidden from a majority, or known only to a few persons). Thus, if we appreciate the connection between truth (as correspondence) and social wellbeing (or meaningful living), then, the attainment of the latter will be more feasible. This is because human existence, which can be simply summed by the word "life", has meaning, and can be constantly improved upon, only in situations where actual human experiences are constantly described as they truly are. Only such actual presentation of reality can lead to life-changing and development-enhancing decisions, policies, and even (where necessary) protests. Understood this way, one would be correct to say that truth (gives meaning to, and therefore) is life. Hence, the meaning-laden Igbo expression "eziokwu bu ndu" ("truth is life").

\section{Eziokwu bu ndu: Exploring the Epistemological-Existential Connection in the Igbo Concept of Truth}

In this section, I am bothered by the simple question: "If 'eziokwu bu ndu' ('Truth is life' or 'Truth leads to meaningful social development') as the Igbos would say, what truths (about her identity, inter-ethnic relations, individuals' commitments to the wellbeing of their societies, and model of social development) do Nigerians need to accept about themselves and their country before their general wellbeing can be guaranteed?” Truth is presented here as the agreement between propositions about a reality and the reality itself. Propositions pose truth-claims; and any proposition which successfully sustains its truth-claim is said to be true. This is why when used in discourses, true propositions lead individuals and groups to know and understand themselves and their world better. Hence, truth in discourses can be used to effect an improved self- and world-understanding. It is the quality and ability of a narrative (or a story) to successfully provide a concordant, more organised and properly linked presentation of reality.

Narratives are descriptions of reality: events, a society's or individual's history, a society's or individual's physical structures, behaviours, and so on. The meaning of human existence is coded in stories because human beings are embedded in stories. David Carr (2003) presents Ricoeur's position on man's embededness in stories. He noted that living means being always caught in stories. If these stories are not actually (or better, truthfully) recounted, they call for such recounting. According to Ricoeur (2003: p. 169), "we tell stories because in the last analysis human lives need and merit being narrated," after all "time becomes human to the extent that it is articulated through a narrative mode." We come into the world already surrounded with narratives. Our identities develop, are given meaning, and are expressed in narratives. This is what is meant here by the Ricoeurean concept "narrative-identity" since in narratives history discloses human actions as well as the identity (values, preferences, and choices) of the "who" of these actions.

It is because of this disclosure of the actions of the "who" of history that it is of utmost importance to insist on an appreciation of the ontological relationship between knowledge (as what is known and expressed in propositional forms), and human flourishing or social development. An appreciation of this relationship is very important because it determines the presentation of the picture of the world to children. It determines how a society commits itself to the payment of what Ricoeur (p. 186) described as "a hanging debt to represent life". This debt 
is such that "either you falsify life, or you represent it". This could be re-stated to mean: either you falsify or wrongly present an identity, or you present it as it is. To present correctly, is to present the truth about life. It is also to make life more meaningful; to increase the possibilities of improving the wellbeing of those who are living. In what follows, I engage in a brief analysis of the Igbo expression "eziokwu bu ndu".

The idea is that what should be presented as the identity of a people on the basis of which they can develop must be the truth about their life because truth (eziokwu) is $(b u)$ life $(n d u)$. This seems like an ontological identification of truthfulness with-or better as a presupposed foundation for-meaningful living. Thus, eziokwu (truth) $b u$ (is) $n d u$ (life) could still be re-interpreted to mean that truth is the only principle that makes life meaningful. This last interpretation would mean that the Igbo expression "eziokwu bu ndu" establishes an inevitable and ontological link between 1) knowledge (for instance: self-knowledge, self-understanding, world-understanding, how what is known and understood is handled and used to reveal or conceal reality, and so on) and 2) the mode of existence of a subject (person or society). To ignore this principle (truth) or to attempt to conceal it, would therefore mean to have worked (or to be working) against the primary principle for meaningful existence-the primary condition for fruitful assessment of facts and situations. It means to ignore life and its quest to be constantly improved. To deny the facts about a self or a people is to willingly engage in baseless, false and therefore useless assessments. Such assessments would definitely lead to useless results. The consequence is stagnation, lack of improvement, in fact, underdevelopment, as defines Nigeria.

The above ideas can be further elucidated by considering the views of Matthew Chukwuelobe (1991). He established an interesting connection among 1) the Igbo word "okwu" (word/language); 2) logos; and 3) the function of disclosure. Chukwuelobe noted that even though language seems to have an affiliation with logos, the two are not the same. The impact of logos, according to him, lies both in its "act of gathering within the togetherness of being" and "in laying bare (legen)". This is because every gathering presupposes a laying which itself brings to lie, in that it lets things lie together before us. What lies before us reveals itself; and because the logos lets lie before us what lies before us as such, it discloses what is present in its preserving. But, disclosure is aletheia, and "the lighting and concealing presencing of the world in itself is 'the essential being of saying"” (p. 38). This implies that saying gathers and discloses being. Discourses, as platforms in which propositions are employed in claiming to truthfully or falsely describe reality, are avenues in which things are said about any aspect of reality. Those who say things in discourses all claim to disclose being as it really is.

On the basis of the above, it is worthwhile to have a second-level consideration of the Igbo expression under analysis. $\mathrm{Okwu}$, as interpreted here, is word, language, and more contextually, speaking/saying. As already indicated, saying can take place in discourses. It can also be represented in different forms of texts. Okwu can be a gathering meant to either disclose (reveal, allow being to happen) or attempt to conceal. I emphasise this second possibility of what can be done with $O k w u$ as what is gathered because every attempt to conceal what is gathered and disclosed about being's (say, a people's) mode of comportment (that is, way of life, approach to reality, and manner of carrying out life's activities) is bound to fail—or at most, succeeds only momentarily. This is based on the fact which Heidegger presented so well, namely, that being's articulation of his comportment is beyond his control. This is because to exist presupposes comporting oneself in some ways or modes; and, all working, achieving, action, calculation, and so on "keep within an open region within which beings, with regard to what they are and how they are, can properly take their stand and become capable of being said” (Heidegger, 1943 [1961]: p. 5). In what is said, there is always the possibility of disclosing or concealing.

It is the distinction between the aim to disclose and the aim to conceal that is represented by the distinction in Igbo language between ezi-okwu as the truthful proposition (that discloses what is gathered or known about being), and okwu-ugha or asi as false proposition (that attempts to conceal what is gathered about being). This means that ezi-okwu is truth also in the correspondence sense. Thus, with regard to the ability of a speaker to choose to use Okwu (more specifically, eziokwu) to reveal what is gathered about being, Chukwuelobe (1991) argued that okwu not only holds sway over man; in an ideal situation, it reveals or discloses what lies hidden in the depth of the mind. Because man is always inclined to deprave or twist okwu (language), the term ezi-okwu (truth) arises for the Igbo, and is assigned two literal meanings in Igbo. It "can either mean the path (ezi) of okwu (language/word) or" more commonly "true word/language. Therefore, truth (ezi-okwu) in Igbo is a path through which language treads. Man who belongs to language must tread this path" because this path "stands for truth itself". Yet, eziokwu is the path, as Chukwuelobe presented above, through which an individual or society can creatively arrive at eziokwu (the true word, language, meaning) as self- and world-understanding about itself. Thus, eziokwu is both a path (as Chukwuelobe and Heidegger argued) and the thing (true word, true meaning,) 
which lies at the end of the path.

It is important to recall the previous analysis of the expression "eziokwu bu ndu" as an ontological identification of truthfulness with—or better, the foundation for-meaningful living; and as meaning that truth is the only principle that makes life meaningful. On the basis of these analyses, it becomes clear how the same expression "eziokwu bu ndu" weakens the postmodern arguments for cultural egalitarianism. The declaration "eziokwu bu $n d u$ " is first of all a challenge, particularly to so many African scholars, against their consistent presentation of false features as constituents of a false-unique African identity. As a challenge, it is a call to self-reflection. The reflexivity that it appeals for, and the challenge that it is, and leads to, constitute the foundation for weakening the appeal to cultural egalitarianism. If this expression ("eziokwu bu ndu") challenges an identity, then, no identity-form is unchangeable, and therefore no culture is so complete that it cannot be adjusted. The adjustment or improvement in one culture may require borrowing some more-humane insights from other cultures. On the basis of this, it could be stated that no culture needs to parade itself as complete. Cultural egalitarianism is false: all cultures are not equal. These imply that the expression under analysis ("eziokwu bu ndu") is an invitation to adopt a model of social development that is rooted in self-reflection and consistent search for the truth about an individual or a society.

It deserves to be noted that because the predominant narrative-identity provided by most African scholars in the humanities focuses on "whom to blame next", the result is that the predominant theory of development (explanations of the factors that determine social development, and or responsible for the development pace of African societies), preferred by such scholars, is the dependency theory. However, it is reasonable to argue that self-conception, contexts, narratives and imagination, determine social development; that identity, understood not as sameness and frozen memories, but as character (values, norms, dispositions, preferences, and ideals) and self-constancy, determine not just influence, the rate of development in Africa. This is why African societies will be better off if their scholars abandon the already sterile dependency theory, and the useless verbal painting of a "once-upon-a-time Eldorado" African societies (that is, Afro-centrism), and opt for the culture-agency development model which properly presents Africans as the self-reflective social agents who alone can make development to happen in Africa.

\section{Conclusion}

I conclude this paper by stating that "it is" only Nigerians who are capable of determining the direction and the nature of the improvement of their wellbeing. To make this possible, Nigerians need to abandon the selfish and irresponsible behaviours that define the actions of majority of the people in all works of life-scholars, business men, teachers, politicians, youths-who lived from 1959 (when the agreement was finalized to make Nigeria an independent state) to 2014 (when the evidence in all spheres of life and meaning, jointly indicate that most of us are selfish and cowards). These last adjectives are so sweeping, and may "seem" unfair. Yet, available facts show that the "set of development choices" we have made have consistently resulted to one thing: "we have been left behind many times over by every one of" the countries that used to be our par on the development ladder (South Korea, Singapore, Malaysia, Chile, Brazil, and a few others) (Ezekwesili, 2013: p. 4). One of these anti-development choices we have consistently made is the refusal to address the question of whether it is reasonable for the major ethnic groups in Nigeria to continue to live together as a single country.

\section{Acknowledgements}

I am grateful to the following individuals: Prof. Joseph Agbakoba and Dr. Matthew Chukwuelobe (CSSp.) (for being sources of inspiration to me), Miss Elizabeth A. Igwe (for her unrelenting encouragement to move ahead), the anonymous OJPP peer-reviewers (for their very useful comments), the OJPP editorial committee for granting me the partial fee waiver which reduced the cost of publishing this paper, and Kingsley Okeke (for his assistance in financing the cost of publication of this paper).

\section{References}

Agbakoba, J. C. A. (1998). Towards a Philosophy of Technology and Development. In J. O. Oguejiofor (Ed.), Africa, Philosophy and Public Affairs (pp. 217-240). Enugu, Delta: African Philosophy and Public Affairs.

Agbakoba, J. C. A. (2003). Philosophical Issues in Development. Enugu: Fourth Dimension Publishers.

Carr, D., Taylor, C., \& Ricoeur, P. (2003). Discussion: Ricoeur on Narrative. In D. Wood (Ed.), On Paul Ricoeur: Narrative 
and Interpretation (pp. 160-187). New York: Routledge.

Chukwuelobe, M. (1991). The Relevance of Heidegger's Articulation of Death to Eschatology from an Igbo Perspective. Ph.D. Dissertation. Duquesne: Graduate School of Duquesne.

Diamond, J. (1997). Guns, Germs, and Steel: The Fate of Human Societies. New York: W.W. Norton \& Company.

Diamond, J. (2005). Collapse: How Societies Choose to Fail or Succeed. New York: Viking/Penguin Group.

Drèze, J., \& Sen, A. (2013). An Uncertain Glory: India and Its Contradictions. New Jersey: Princeton University Press. PMCid:PMC3676057.

Ezekwesili, O. (2013). The Wealth and Poverty of a Nation: Who Shall Restore the Dignity of Nigeria? 42nd Convocation Lecture. University of Nigeria, Nsukka. Nsukka: University Press.

Harrison, L., \& Huntington, S. (2000). Culture Matters: How Values Shape Human Progress. New York: Basic Books.

Harrison, L. E. (1985). What Makes Development Happen?

http://www.jdainternational.org/resources/What\%20development\%20Happen.pdf

Heidegger, M. (1943[1961]). On the Essence of Truth. http://filepedia.org/files/MartinHeidegger-OntheEssenceofTruth.pdf

Landes, D. S. (1999). The Wealth and Poverty of Nations. New York: W.W. Norton.

Meredith, M. (2006). The State of Africa: A History of Fifty Years of Independence. New York: Free Press.

Meyns, P., \& Musamba, C., Eds. (2010). The Developmental State in Africa: Problems and Prospects. Duisburg and Essen: Institute for Development and Peace, University of Duisburg-Essen.

Mkandawire, T. (2001). Thinking about Developmental States in Africa. Cambridge Journal of Economics, 25, $289-313$. http://dx.doi.org/10.1093/cje/25.3.289

Musamba, C. (2010). The Developmental State Concept and Its Relevance for Africa. In P. Meyns, \& C. Mu-samba (Eds.), The Developmental State in Africa: Problems and Prospects (pp. 11-41). Duisburg and Essen: Institute for Development and Peace, University of Duisburg-Essen.

Njoku, F. O. C. (2004). Development and African Philosophy: A Theoretical Reconstruction of African Socio-Political Economy. New York: iUniverse.

Nussbaum, M. C. (2001). Women and Human Development: The Capabilities Approach. Cambridge: Cambridge University Press. http://dx.doi.org/10.1017/CBO9780511841286

Nussbaum, M. C., \& Sen, A. (Eds.) (1993). The Quality of Life. Oxford: Clarendon Press. http://dx.doi.org/10.1093/0198287976.001.0001

Oguejiofor, J. O. (2001). Philosophy and the African Predicament. Ibadan: Hope Publications.

Rodney, W. (1972). How Europe Underdeveloped Africa. Lagos: Panaf Publishing, Inc.

Sachs, J. (2005). The End of Poverty: How We Can Make It Happen in Our Lifetime. New York: Penguin Books.

Sen, A. (2000). Development as Freedom. New York: Alfred A. Knopf.

Stark, R. (2005). The Victory of Reason: How Christianity Led to Freedom, Capitalism and Western Success. New York: Random House.

Weber, M. (1930). The Protestant Ethic and the Spirit of Capitalism. Translated by T. Parsons, London: Routledge—-Taylor and Francis Group.

Willis, K. (2005). Theories and Practices of Development. London: Routledge. 
Scientific Research Publishing (SCIRP) is one of the largest Open Access journal publishers. It is currently publishing more than 200 open access, online, peer-reviewed journals covering a wide range of academic disciplines. SCIRP serves the worldwide academic communities and contributes to the progress and application of science with its publication.

Other selected journals from SCIRP are listed as below. Submit your manuscript to us via either submit@scirp.org or Online Submission Portal.
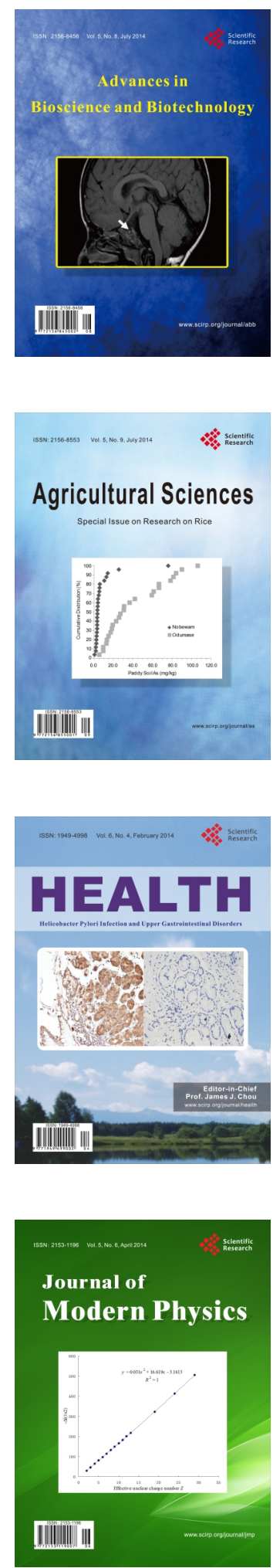
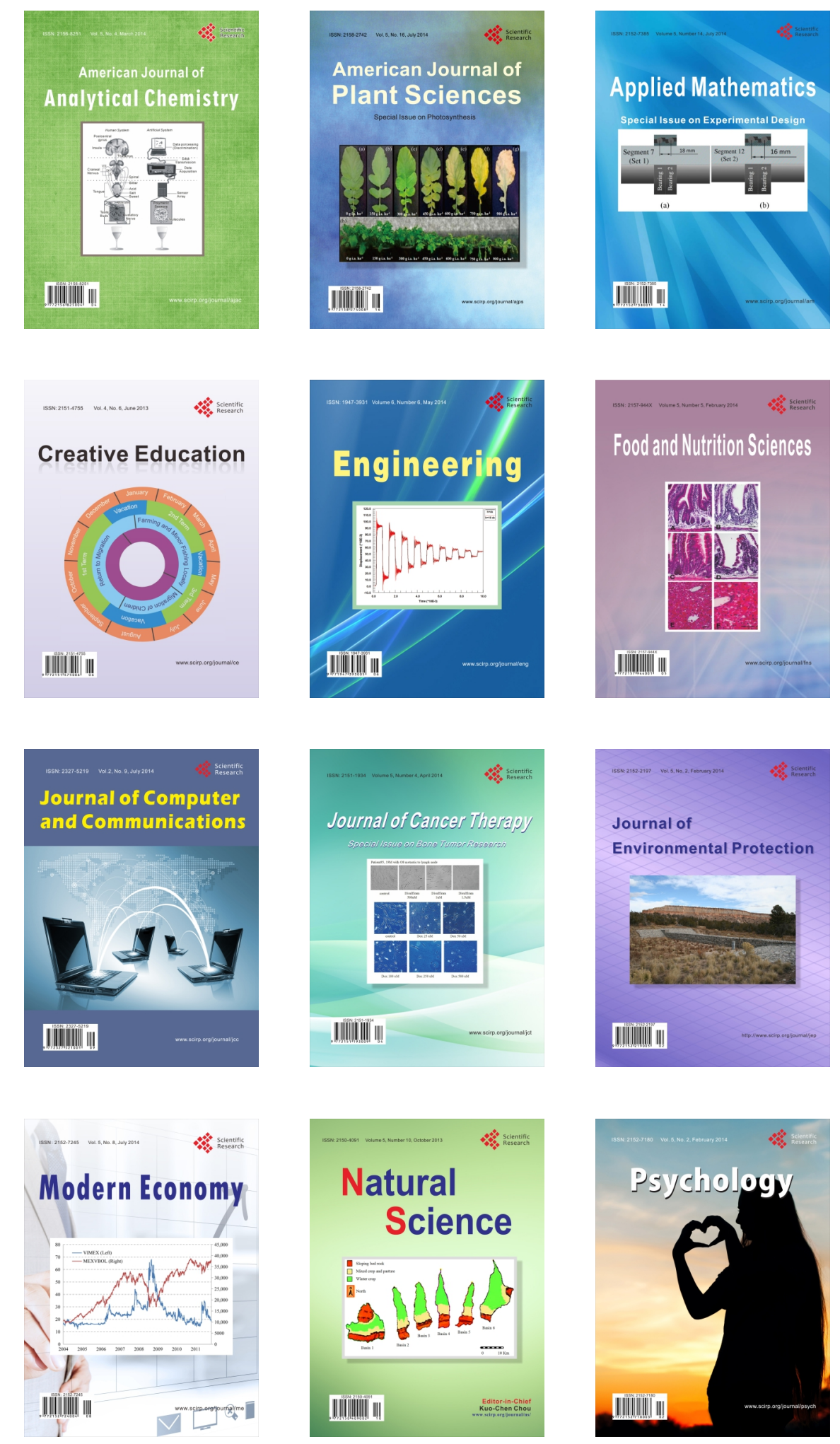